\title{
Problematizing Dalit Chetna: Sadgati as the Battleground of Conflict between the 'Progressive Casteless Consciousness' and the Anti-Caste Dalit Consciousness
}

\author{
Sumit Rajak \\ Assistant Professor of English, S.B.S. Government College, Hili, Dakshin Dinajpur, India, $\mathcal{E}$ \\ Ph.D. researcher, Department of English, Jadavpur University, Kolkata, India. \\ Email: rajaksumit111@gmail.com
}

\begin{abstract}
The notion of Dalit chetna or Dalit consciousness is central to the development of the anti-caste discourse. Since the inception of a visible and radical Dalit discourse, a paramount importance has been accorded to the idea of Dalit consciousness. Whereas the prevalence of Dalit consciousness is of paramount importance to the Dalit writers, filmmakers and critics, and there is a vibrant presence of this consciousness in their works, there has also been an attempt on the part of the upper-caste writers and filmmakers to engage with the Dalit consciousness on their own terms, and thereby developing what I call 'progressive casteless consciousness', which is not synonymous with the anti-caste Dalit consciousness developed by the Dalit writers, filmmakers among others, in their works. This paper is an attempt to explore these distinct versions of Dalit consciousness through a reading of the representation of the caste questions in the celebrated Hindi writer Munshi Premchand's widely read short story Sadgati ('deliverance' in the religious sense of the term), which he composed in 1931, and its film adaptation by the globally acclaimed filmmaker Satyajit Ray in the form of a TV film Sadgati (1981), and the critical writings on the writer and the director's handling of the caste questions. In the process, the paper will show how Sadgati, both of Premchand and of Satyajit Ray, becomes the repository of conflict between the progressive casteless consciousness of the upper-caste intellectuals and the anti-caste Dalit consciousness developed by the Dalit intellectuals.
\end{abstract}

Keywords: Dalit consciousness, repository of conflict, adaptation, battleground of representation, progressive casteless consciousness, anti-caste Dalit consciousness

\section{Introduction}

The notion of Dalit chetna or Dalit consciousness has been one of the core aspects in the anticaste discourse. From the aesthetic point of view it remains an indispensable aspect in identifying the aesthetics of Dalit literature or cinema or any piece of creative work. Since the inception of a visible and radical Dalit discourse, a paramount importance has been accorded to the idea of Dalit consciousness. The prominent Dalit intellectuals, who include Dalit writers, artists, critics and filmmakers among others, emphasize time and again the question of Dalit consciousness in defining Dalit literature or cinema. Whereas the prevalence of Dalit consciousness is of utmost importance to the Dalit writers, filmmakers and critics, and there is a vibrant presence of this

(C) AesthetixMS 2020. This Open Access article is published under a Creative Commons Attribution Non-Commercial 4.o International License (http://creativecommons.org/licenses/by-nc/4.o/), which permits non-commercial re-use, distribution, and reproduction in any medium, provided the original work is properly cited. For citation use the DOI. For commercial re-use, please contact editor@rupkatha.com. 
consciousness in their works, there has also been an attempt on the part of the upper-caste writers and filmmakers to engage with the Dalit consciousness on their own terms, and thereby developing what I call 'progressive casteless consciousness', which is not synonymous with the anti-caste Dalit consciousness developed by the Dalit writers, filmmakers among others, in their works. This paper is an attempt to explore these distinct versions of Dalit consciousness through a reading of the representation of the caste questions in the celebrated Hindi writer Munshi Premchand's widely read short story Sadgati ('deliverance' in the religious sense of the term), which he composed in 1931, and its film adaptation by the globally acclaimed filmmaker Satyajit Ray in the form of a TV film Sadgati (1981), and the critical writings on the writer and the director's handling of the caste questions. In the process, the paper will show how Sadgati, both of Premchand (1880-1936) and of Satyajit Ray (1921-1992), becomes the repository of conflict between the 'progressive casteless consciousness' of the upper-caste intellectuals and the anti-caste Dalit consciousness developed by the Dalit intellectuals.

To define Dalit literature, the celebrated Marathi Dalit writer Sharankumar Limbale in his seminal book on Dalit literature and criticism, Towards an Aesthetic of Dalit Literature: History, Controversies and Considerations, writes: 'By Dalit Literature, I mean writing about Dalits by Dalit writers with a Dalit consciousness' (Limbale, 2004, 2016, p.19). He further enunciates his view as to the question of a text's criteria as a Dalit text when he explains: 'the standard of a work of literature depends on how much and in what way an artist's ideas-embedded in the workaffect the reader. Dalit writers will have to decide how best to express Ambedkarite thought in their literature. That work of Dalit literature will be recognized as beautiful, and, therefore "good", which causes the greatest awakening of Dalit consciousness in the reader' (ibid., p.117). The concept of Dalit chetna or Dalit consciousness has been elucidated by the prominent Hindi Dalit writer and critic Omprakash Valmiki in his Dalit Sahitya ka Saundarya Sastra (Aesthetics of Dalit Literature) in the following words:

Just describing or explaining the pain, sorrow, anguish, exploitation is not Dalit consciousness, nor the emotional or eye-watering narration of Dalit pain, which is devoid of fundamental consciousness; consciousness has a direct relation with perspective which breaks the charm of image of Dalits' cultural, historical and social role. This is called Dalit consciousness. Dalit means someone who is deprived of human rights, someone who has been socially unaccepted. His consciousness is what constitutes Dalit consciousness. (Translation mine). (Valmiki, 2014, 2019, p. 29)

Renu Josan in her article "Oppression to Assertion: Dalit Consciousness in Omprakash Valmiki's Joothan" underlines Valmiki's interpretation of Dalit consciousness as a crucial cultural tool which is 'elemental in opposing the cultural inheritance of the upper castes, the notion that culture is a hereditary right for them and one that is denied to Dalits' (Josan, 2012, p. 8). Like Limbale, Sharatchandra Muktibodh, a prominent Marathi literary critic, considers Dalit consciousness as the core constitutive element in the production of Dalit literature when he argues, in his article "What is Dalit Literature", that "Dalit literature is the literature produced by the Dalit consciousness' (Muktibodh, 1992, p. 267). He argues that Dalit consciousness is the defining nature of Dalit literature which embodies 'a rebellion against the suppression and humiliation suffered by the Dalits - in the past and even at present-in the framework of the varna system' (Muktibodh, 1992, p. 267). Defining Dalit chetna as 'an experiential and political perspective made up of the firsthand knowledge of caste-based oppression and atrocity, along with the political goal of a liberating awakening that results from the exposure of this atrocity as central to the maintenance of caste hierarchies', Laura Brueck (2010) in her article "The Emerging 
Complexity of Dalit Consciousness" discusses the inherent complexity in the very notion of Dalit chetna. She problematizes the idea of Dalit chetna by arguing that there is an underlying process of marginalization within the margin as there is a tendency by the writers and the readers, who consider only the 'male-centred and rural stories' to be 'most expressive of Dalit chetna', to label the narratives of the women, urban-dwelling, middle-class Dalits as less authentic (2010, p. 44). Whereas most of the Dalit writers and critics insist on the essentialization of 'Dalit chetna' in the creation and critical evaluation of Dalit texts, Anita Bharti, the General Secretary of the Delhibased literary organization Dalit Lekhak Sangh (Dalit Writers' Collective), as noted by Brueck in her article, points out serious limitation in the idea of Dalit chetna as constructed and defined by the Dalit authors and critics (2010, p. 46). She argues that there is no space for Dalit feminist perspective in the commonplace notion of Dalit chetna. Moreover, as she points out, the urban, middle class Dalits find it difficult to put their individual urban experiences of alienation or crisis of modern life into the narratives of oppression and atrocity in the rural sphere, and thereby have their own narratives considered less authentic. Although undergoing a different experience due to spatial mobility, they are 'forcibly' made to articulate their narratives in a way that these narratives come under the oeuvre of a monolithic Dalit chetna.

Although the notion of Dalit chetna gets questioned by a the likes of Anita Bharti, the constant emphasis of the Dalit writers and critics on Dalit consciousness as the defining characteristic in evaluating the 'Dalit-ness' of a text over the years attests to the magnitude of its importance in the discussion of texts based on the caste questions or any Dalit issue. Not to mention, the demystification of the nature of Dalit consciousness developed by the Dalit writers and critics will reveal that it carries within it an anti-caste characteristic which involves a sense of resistance, rage or anger against the atrocities, oppressions or discrimination emanated from ageold caste system, and a determination or endeavour to abolish the system and structure of casteism. Unlike this anti-caste rhetoric in the Dalit consciousness developed by the Dalit intellectuals, the upper-caste intellectuals, mostly writers, filmmakers, critics, develop in their works what I call a 'progressive casteless consciousness' which involves the act of raising awareness among the readers and viewers through the depiction of suffering, pain, discrimination, humiliation of the Dalits caused by the upper-caste fellows, hardly developing any counter-narrative to the system of caste. I have deployed the epithet 'progressive' because there is a tendency on the part of the upper-caste intellectuals to consider it 'progressive' to offer a sympathetic approach to Dalit cause, although that how this approach contributes to developing an anti-caste discourse remains highly questionable and faces severe backlash from the Dalit intellectual circle. A scrutiny of Premchand's short story Sadgati and Satyajit Ray's film adaptation of the same, and the critical responses from both the Dalit and non-Dalit writers, critics and intellectuals to both the writer and the filmmaker's handling the Dalit issue will reveal how Sadgati becomes the repository of conflict to find a consciousness which will render a greater service to Dalit cause.

It is the representation [emphasis mine] of the caste questions and the Dalit characters in the story which becomes a repository of conflict generally between the upper-caste writers and critics and their Dalit counterparts after the emergence of a visible anti-caste discourse, and this conflict is concerned with the upper-caste writer and the upper-caste filmmaker's approach in handling a caste or Dalit issue in their works. The critical writings in assessing the caste questions in Premchand's writings on Dalit lives reveal a huge controversy, and the resultant division among the Dalit writers and critics and their upper-caste counterparts. Shashi Bhushan 
Upadhyay, an Associate Professor at IGNOU, aptly describes this conflict in the introduction of his article "Premchand and Dalit Literature: Representation of Dalits in the Literature of Premchand":

On the one hand, there are writers who consider that Premchand was not only sympathetic to the cause of the Dalits but also that he gave to the Dalits a realist portrayal and a voice through his literature. They aver that Premchand's writings may be considered as part of Dalit literature. On the other hand, the Hindi Dalit writers react strongly to any such contention. They say that Premchand, like other high-caste writers, was not capable of realistically portraying the Dalits and their woes. In fact, they say, Premchand misrepresents them, and in certain cases like in 'Kafan', he has vilified the Dalits. The attack by some of the Hindi Dalit writers is so severe that they even refuse toconsider Premchand as sympathetic to the Dalit cause.(Ahmad and Upadhyay, 2010, p.156)

Before delving into the exploration of the caste questions to understand how the idea of Dalit consciousness becomes the repository of conflict, I will delve into the story of Sadgati in the following section.

\section{Dukhi's Sadgati}

The story of Sadgati revolves around the tragic lives of the Dalit characters Dukhi, his wife Jhuria and their daughter Dhaniya whose marriage has been fixed at her early teenage. Dukhi, the untouchable chamar (an untouchable caste according to the hierarchical caste system), goes to the local village priest Ghasiram in order to invite him to his abode for fixing an auspicious date and time for her daughter's marriage (as per the Hindu belief system, fixing the date and time of one's marriage by some representative of God, here the Brahmin pundit, is considered to be sacred and auspicious, and a deviation from this custom may bring in unhappiness in the conjugal life of the newly married couple). The Brahmin pundit takes this as an 'opportunity' to get some strenuous works done by Dukhi, as he knows that Dukhi is compelled to follow his order because Dukhi is religiously bound to ask him for fixing the auspicious date and time of his daughter's marriage. As is expected, Dukhi follows every single order of the pundit and completes all the household chores given to him without any protest. But the cunningness of the pundit and his cruelty towards Dukhi do not stop here. Dukhi, who has already been suffering from a bout of fever, and who is already with an empty stomach, is ordered to chop a huge chunk of wood into splints. Under the scorching heat of the sun, the exhausted Dukhi hits the gigantic chunk of wood with an axe with all his remaining strength, but remain unsuccessful in chopping the log. When the cruel pundit scolds him for his failure to chop the wood and threatens to fix an inauspicious date and time for his daughter's marriage, Dukhi, out of fear and out of rage to the irony of his fate, starts to blow the log until he finally collapses at the spot only to die a lingering death. Now, one of the cruelest parts of the untouchable's life is that the curse of untouchability does not spare them even after their death, and there is no exception to Dukhi's fate. When the pundit approaches the chamars of the village to dispose the dead body of Dukhi, they, suggested by some Gond, a tribal, who witnessed Dukhi being exploited by the pundit, refuse to take it out of the village, and rather accuse the pundit for Dukhi's death as it is he who orders Dukhi to undertake excessive and strenuous tasks of the former's household. The other Brahmins of the village also ask the pundit to dispose the dead body as early as possible because they cannot endure the matter that an untouchable's body is lying on the way to the village well. The presence of an untouchable's corpse creates much disturbance and inconvenience on the way to the village well. 
Under such circumstances, with no other option left, the pundit has to take the responsibility of disposing the dead body of Dukhi out of the village with utter disdain. Dragging the dead body all along the village road with a rope, the inhuman pundit disposes or, to use the religious term, 'deliver' the corpse amidst the carcass of cattle at the outskirts of the village, the place where an untouchable 'deserves' to belong to. This is the way Dukhi achieves 'sadgati' (according to the Hindu belief system, 'sadgati' refers to the happy state of the soul after one's death, and it is a state which can be achieved only after some rituals done by the representatives of God, i.e., the Brahmin pandits). The pathetic Jhuria's lamentation at her husband's death adds more density to the tragic character of their lives.

Both the literary text and its film adaptation portray the Dalit character Dukhi chamar (tanner) as submissive, oppressed and subhuman. The caste order has made Dukhi accept his fate that he has been born to be exploited. Even he has the belief to the extent that it is sacred to be exploited by a Brahmin priest, that it is better to be exploited than cursed by a Brahmin priest. What both the writer and the filmmaker focus in their works is a Dalit's exploitation by a Brahmin, his submission to a fate constructed by the religiously sanctioned caste system, a subhuman existence which is devoid of a sense of resistance. It is through the representation of these aspects of a Dalit's life that both the upper-caste writer and the filmmaker attempt to raise awareness against the practice of caste system and untouchability. In the following section I will discuss how the exploitation and submissiveness of a Dalit has been represented in both the literary text and its film adaptation.

\section{Hindu Social Order and the Exploitation of a Dalit}

'Seeing Panditji's resplendent face, his heart was filled with respect. What a divine figure! A short, rotund man with a bald head, puffy cheeks and a divine glow in his eyes! The red powder and sandalwood paste him with a godlike aura' (Premchand, 2018, p. 8). It is the Brahmanical social order which shapes the Dalits' ways of viewing the members of the other castes as well their entire outlook to society. Dalits are well-aware of their lowly position in the caste-ridden societal hierarchy. And this position compels them to pay unconditional respect to the high-caste fellows. Dukhi's act of prostrating before the priest, his bowed head, his consent to follow the Brahmin pandit's order are indicative of the unconditional subordination of a Dalit to a Brahmin. He believes that the act of smoking tobacco is an act done by the lower caste folks. The Brahmins do not subscribe to the act of smoking. To the wife of the Brahmin pandit (priest), Dukhi's asking for fire appears to be an audacious act. She believes that in allowing her to give fire to the untouchable Dukhi, the pandit is violating the tenets of religion. A Dalit is so low-born that he does not qualify for a Brahmin's fellowship. Dukhi is conscious of the purity-pollution dichotomy in the caste structure in which the high-castes are considered to be 'pure', whereas the low-castes are considered to be 'polluted' or 'impure'. When he, after getting struck by the live fire thrown at him by the Brahmin pandit's wife, says 'This is the punishment for polluting a holy Brahmin's sacred house' (ibid., p. 11) he is considering his Dalit body to be a 'polluted' one.

\section{Imaging Segregation, Dalit body, and Precarity of a Dalit}

The film Sadgati (1981) recounts the story of Premchand's Sadgati in its characteristic mode of showing. Directed by Satyajit Ray, and produced by Doordarshan, the film won the Special Jury 
Award in 1981. This cinematic version can be considered what is usually referred as the faithful adaptation of the original text in the discipline of adaptation studies. But as characteristic to Satyajit Ray's art house films, the category of films he pioneered in Indian cinema with his globally acclaimed 1955 film Pather Panchali (Song of the Road), this TV film is concerned more with realism and humanism than with the polemics of caste. It is in order to attain a 'plausibility and a desirable regime of verisimilitude' (Ray, 1976) that Ray takes resort to art house cinema. In rendering a realistic portrayal of Premchand's story, Ray does not deviate from his cherished artistic sensibilities. As is the case with Ray, the director of the film, he was highly influenced by the Italian neo-realist films, especially those by Vittorio De Sica. As characteristic to neo-realist cinema, Ray mostly chose, as is the case with most of his films, natural locations to shoot this film and intended 'the backdrop of each shot to speak for itself' (Essays, UK, 2018). Moreover, Satyajit Ray was preoccupied with, as put forward by the film critic Moinak Biswas, the 'visual essence of cinema' (1999, p. 13). In Ray's own words, “Ideally, the director should be his own cameraman or at least be able to impose a visual approach on his cameraman" (Ray, 1976). In representing the precarity and exploitation of a low-caste community by the Brahiminical social order Ray relies more on the visuals than on the dialogues. Accordingly, his film Sadgati creates some visuals which capture the plight of the protagonist Dukhi (Om Puri) in particular and the Dalits in general:
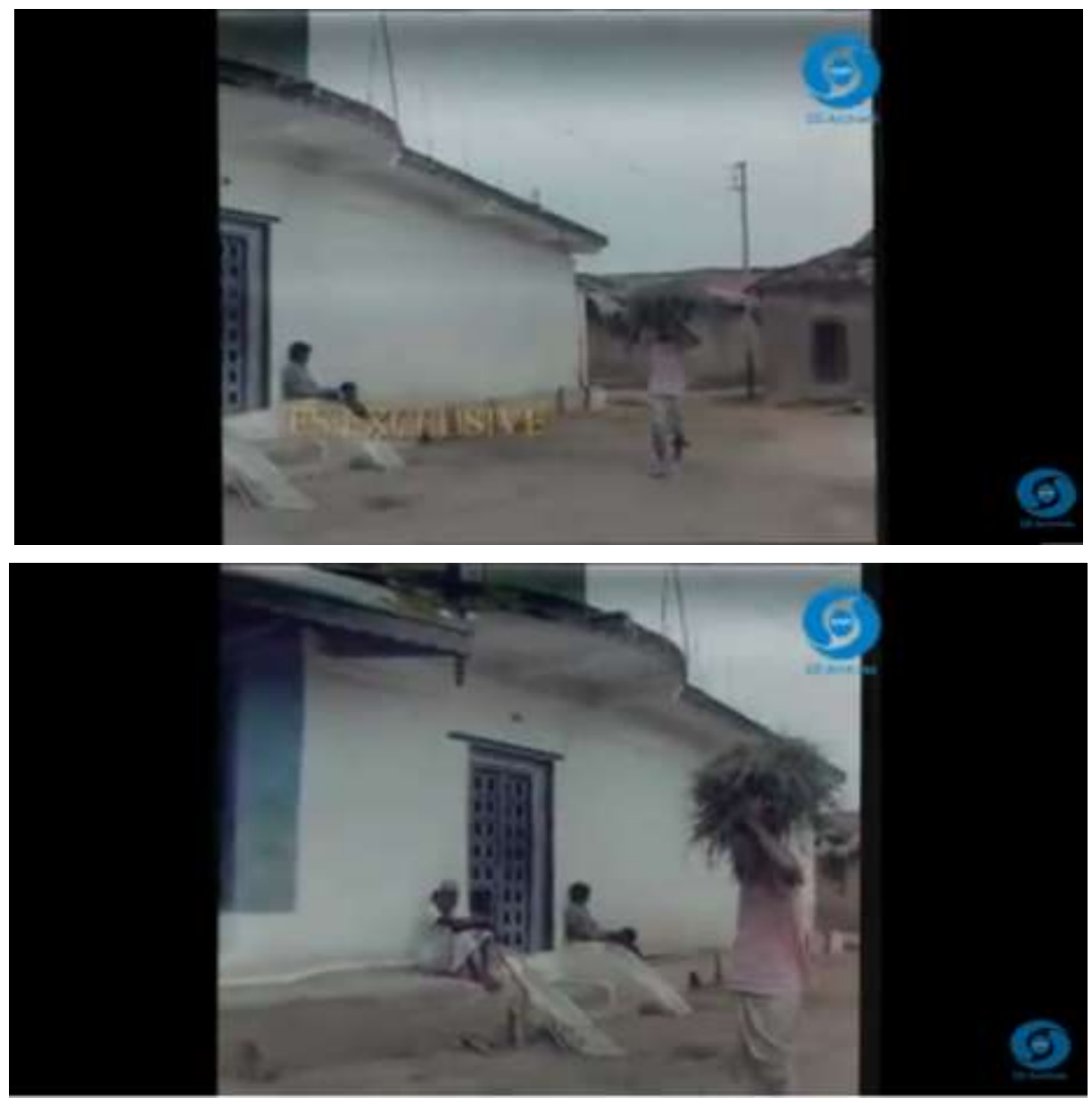


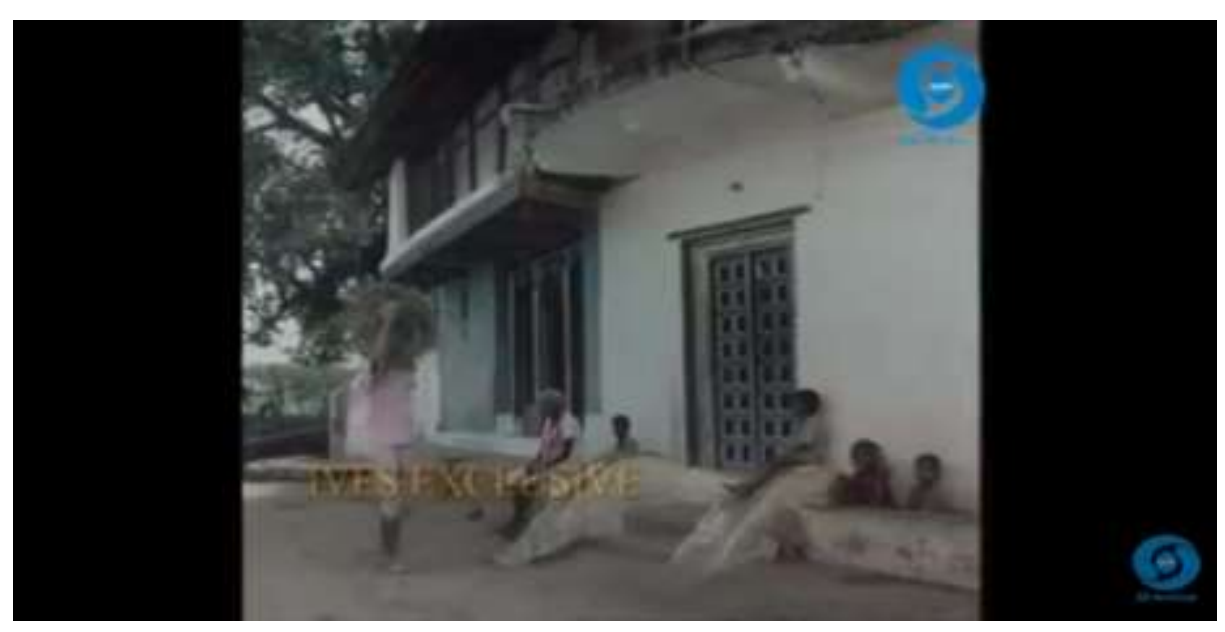

In this sequence, the panning of the camera while taking the shot of Dukhi walking with a bundle of haystack loaded on his head through the Chamar basti to reach the house of the Brahmin priest (Mohan Agashe) shows the visuals which inform the viewers about the precarious condition of the Chamar neighborhood and the Chamars, which include both the children and grown-up men with their dilapidated Dalit bodies, who live at the outskirts of the village. The film also shows some visuals of Dukhi's hut which is disconnected from the main village which is exclusively inhabited by the upper-castes. The Brahmin pandit is found to have mentioned certain 'Chamar basti' (literally, a colony exclusively inhabited by the people of tanner community) where he goes to inform the Chamars about Dukhi's death and ask them to take the dead body away, and this explicitly indicates the existence of a separate tanner colony outside the village. It is the characteristic of the Brahmanical casteist society to have separate colonies for the high-castes and the low-castes or the untouchables. As far as the visuals of Dalit body is concerned, the very scene in which the Brahmin pandit comes to the Chamar basti to inform the Chamars about Dukhi's death and ask them to take the corpse away presents a stark contrast between a Brahmin body represented by the Brahmin pandit and a Dalit body represented by the Chamars of the Chamar basti. This contrast has been highlighted with the technique of intercuts in the following scene:

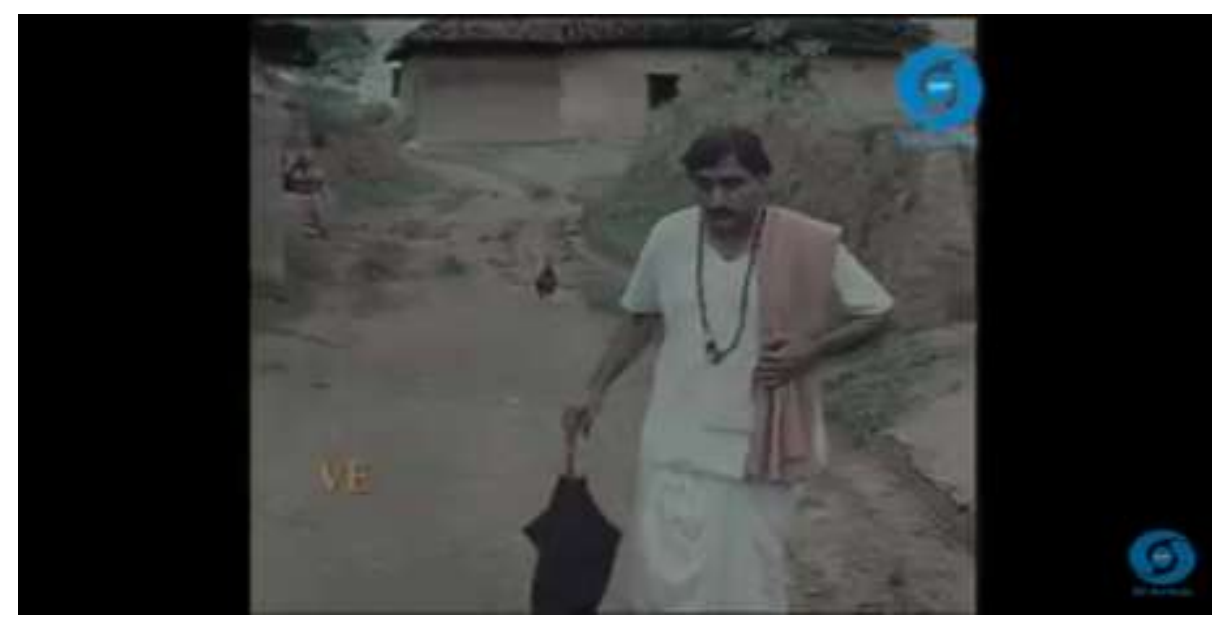




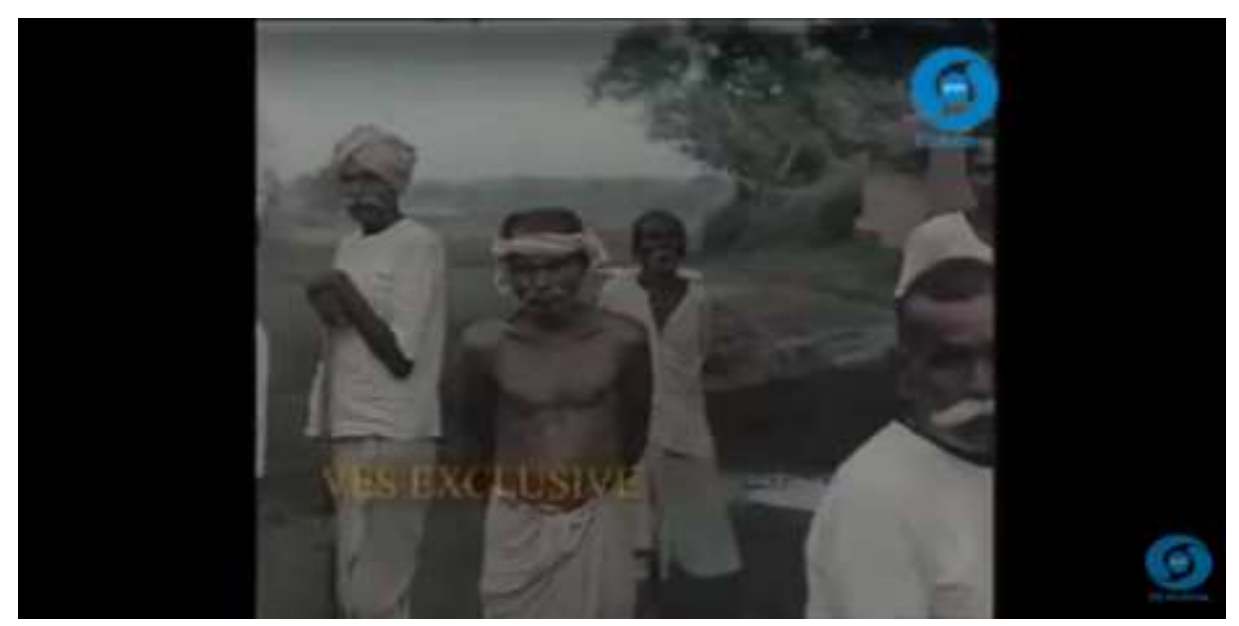

The following frames, which consist of an extreme close-up of Dukhi (Om Puri) and Jhuria (Smita Patil), capture the intense pathos, precarity, exploitation, and helpless state of Dalits conditioned by the Brahmanical social order from which there is no escape.
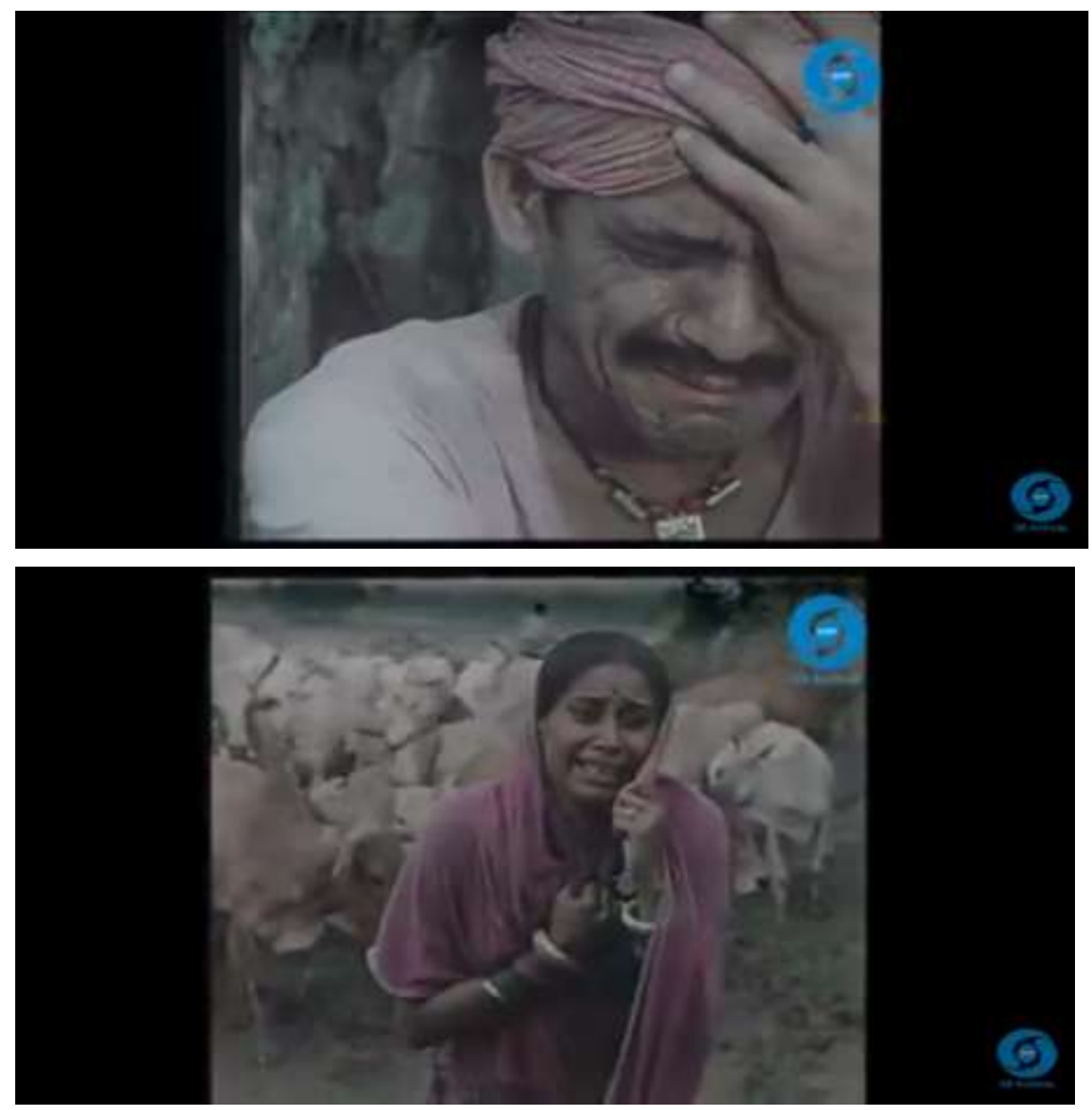

It is this exclusive focus on the submissiveness, exploitation and suffering of the Dalits on the part of both the upper-caste writer and filmmaker that compels the Dalit critics to question the representation of Dalit question in their works. 
As this paper attempts to examine Premchand's approach to the portrayal of Dalits in his works apropos his short story Sadgati, and Ray's treatment of the same in the film adaptation Sadgati, it will also delve into understanding the representation of Dalits through examining some select critical writings on the subject.

\section{Dalit body as the Battleground of Representation}

While commenting on the portrayal of the central character of the story Dukhi, Shashi Bhushan Upadhyay in his article "Premchand and Dalit Literature: Representation of Dalits in the Literature of Premchand" argues:

Dukhi is so completely grounded under the weight of tradition and Brahmanical superiority that he considers himself a non-entity before the spiritual might of the Brahman. He is so laden with his consciousness of being an untouchable that he follows those norms even when there is nobody to observe or enforce it...Even when he gets burnt in the process of getting fire from the Brahman's wife [Panditayin] for lighting his beedi, he does not get angry, upset or irritated. Instead he blames himself for violating the sanctity of a Brahman's house and thinks that this 'punishment' was welldeserved'(Upadhyay in Ahmad and Upadhyay, 2010, p.172).

To substantiate his view of Dukhi's considering himself as a non-entity before the Brahmans, Upadhyay quotes Dukhi's words:

She was speaking the truth-how could a tanner ever come into a Brahman's house? These people were clean and holy, that was why the whole world worshipped and respected them. A mere tanner was absolutely nothing. (ibid., p.173)

Upadhyay's comment that 'Dukhi represents the conscious ultimate in subjection. His acceptance of the Brahmanical dominance is total. He does not resent even in thoughts' (ibid. 173) is what sums up his critical view on the representation of Dalits in Premchand's Sadgati. Nishat Haider, in "In Quest of a Comparative Poetics: A Study of Sadgati", also describes the portrayal of Dalit character's in Premchand's story in almost same manner: 'Characterized by failure, lack and inadequacy, most of the Dalit-speaking subjects are silent sufferers who bend beneath the lashes of undeserved fate, and encounter expressivity or volubility in others without counter-poising their own expressions of suffering' (Haider, in Asaduddin, 2016, p. 206). Yashika Kant in her research article "Approaching the Question of Caste Subjugation in Premchand's Stories Kafan and Sadgati and Analyzing them with Reference to Dominant Trends Noticed in Dalit Literature" explains the portrayal of Dalits in the following words: 'Sadgati vividly sketches the pitiless plight of the Chamars in the discredited lives they lead and the ignominious death they face. The backbreaking toil that extracts Dukhi's life ironically places his body in a no-man's land where it is lies unclaimed.' (Kant, 2017, p. 192). Owing to Madhulika Nirmal's argument that "On certain occasions, Non-dalit writers try to show 'pity' on a Dalit character yet at no point their hero is a dalit rebellion in true sense of Dalit revolt against the brahmanical hierarchy. Non-Dalit's Dalit is a victim of exploitation, most downtrodden who must not be touched and whose very shadow is polluted" (Nirmal, as quoted in Kant, 2017, p. 191), Yashika Kant equates such characteristics in the character of Dukhi. Dukhi's acceptance of punishment as a divine justice as a result of transgressing a Brahmanical space attests Wilfred's argument that "The dominating exercise of 
power takes an insidious form when the present order is internalized by the Dalits...”(Wilfred, as quoted in Kant, 2017, p. 191).

It is such kind of portrayal of Dalit characters as submissive, voiceless non-entity that has been repository of conflict between the group of writers and critics who consider such portrayal of Dalits as appropriate and the group of writers and critics who vehemently attack this sort of depiction of Dalit characters. This debate arises after the emergence of canonical Dalit Literature. Dalit writers and critics such as Kanval Bharti, in 'Dalit Sahitya aur Premchand' ('Dalit Literature and Premchand'), deny Premchand's writings on Dalit issues as part of Dalit Literature, and it is denied on the basis of lack of Dalit consciousness in Premchand's writings. Bharti argues:

I am not saying that Premchand was against Dalits or that I am against Premchand. Only that when doing an evaluation of Premchand as part of Dalit literature, it should be according to Dalit consciousness and thus, Dalit writers' remarks on Premchand are based on and show respect for the authority of Dalit consciousness. (Bharti, as quoted in Hunt, 2014, p.239).

In 'Dalit Sahitya ki Avadharana' ('The Concept of Dalit Literature') also, Bharti questions Premchand's perspective in handling the caste question in his works:

[w]e [Dalit writers] don't accept [Premchand's] perspective because he is a Gandhian and also he didn't have the ideology of struggle. Premchand was not Dalit. He had seen Dalit life from far away. For this reason, his literature...could be called literature of sympathy. (ibid., p. 238).

The noted Dalit critic Raj Kumar dismisses Premchand among others as an appropriate writer to write on Dalit issues on the basis of his non-Dalit identity. As he argues:

Even the most progressive and revolutionary minded writers like Premchand, Mulk Raj Anand, T.S. Pillai, V.S. Khandekar and several others who have tried to describe the sentiments of Dalits are not acceptable; only a Dalit by birth can have the sensitivity and experience to be a genuine Dalit writer. (Kumar, in Ahmad and Upadhyay, 2010, p. 133)

On the other hand, Purushottam Agarwal, a noted Hindi scholar at Jawaharlal Nehru University, puts greater emphasis on the literary category 'imagination' which, according to him, provides license to a writer to write from any particular point of view, here from a Dalit's perspective. The caste identity of the writer does not matter in grappling with a caste or Dalit issue in his or her writing. (Hunt, 2014, p. 222). Dr. Anamika Srivastav admires Premchand's 'sensitive way of writing about dalits'. The author's argument is that Premchand was 'opposed to hierarchy and untouchability, focusing instead on human progress and expressing concern over the situation of marginalized groups such as Dalits, women, and the poor. Premchand's stories, according to Srivastav (1998), are not simply about Dalit oppression, but also about Dalits' power and rights' (Hunt, 2014, p. 237-38). Not to mention, these arguments oppose the Dalit writers' and critics' constant insistence in having a Dalit identity of the writer to deal with a caste or Dalit issue in his or her writing.

As Premchand's depiction of the caste questions in Sadgati, as is the case with some of his other works like Kafan (1936) or Godaan (1936), becomes the battleground for carving out the appropriate Dalit consciousness, Ray's depiction of the same in his film adaptation Sadgati resurfaces the debate, which is evident in some critical writings in response to this. The cinematic text, by virtue of its medium-specific characteristics, offers, as Nishat Haider argues in "In Quest of a Comparative Poetics: A Study of Sadgati", itself as 'a site of suggestions that, to a certain 
extent, the viewer must complete...The viewer actively constructs what she/he see: she/he chooses some specifics of the image and ignores others, and finds fissures in narrative by filling in factual information, through construal extrapolation, that the film allows but does not furnish' (Haider, in Asaduddin, 2016, p. 207). Perhaps these 'fissures' have been best figured out in Deepti Zutshi's article 'Satyajit Ray's Deliverance of Premchand's 'Sadgati':

Ray's adaptation of 'Sadgati' suggests that he could not grapple with the subject the way in which Premchand had (perhaps owing to his progressive politics with a socialist bias) although he had dealt with themes relating to poverty, unemployment, as well as rustic life in several of his films commenting on the crisis of the times. While Premchand seems firmly grounded in his understanding of the socio-political matrix that creates innumerable Gordian knots in the death-like existence of dalits (which one is often ignorant of, or even worse, indifferent towards), Ray's treatment of themes in most of his films appears to revolve around the 'human predicament' as more of an abstraction. While this approach also corroborates the creation of 'meaningful cinema', it fails to realize the authenticity and the complexity of the dalit experience, and instead of raising the consciousness of the viewer, raises questions on Ray's own consciousness with regard to the issue. (Zutshi, in Asaduddin and Ghosh, 2012, p. 240)

Zutshi's argument points out Satyajit Ray's penchant for the art of filming the plight of an untouchable's cursed life as one among several 'human predicament(s)', which have been portrayed in a number of parallel films made in the 1980s. But the author considers the film to be a failure in addressing the 'complexity of the dalit question', and the film's handling of the caste question puts question mark on the director's notion of caste question itself. The author also points out that whereas Premchand's representation of caste questions still remains questionable, Ray's film adaptation furthers the dilution of anti-caste Dalit consciousness as it fails to raise caste consciousness which even Premchand does successfully to some extent. As the author argues:

While Premchand himself has been criticized by 'dalit' writers as having presented generalized discourses of pity while dealing with subjects related to the lives of dalits, it is evident that his works stem from a profound engagement with the question of caste and untouchability that pre-Independence India was fraught with. Through some of his stories like 'Sadgati', he occasionally thrusts questions and statements at the readers that are capable of creating ripples in the smooth waters of the reader's probable indifference towards those problems. Satyajit Ray, on the other hand, in his adaptation of the short story moves a considerable distance away from Premchand and completely dilutes this aspect in his presentation. (Zutshi, in Asaduddin and Ghosh, 2012, p. 240)

However, Ray's problematic position on the polemics of caste does not undermine his seriousness and sensitivity in approaching a social institution like caste. As rightly pointed out by the renowned film critic Darius Cooper, '...beneath the variety of narrative discourses he develops, Ray is intent in telling us another story. In film after film, he investigates India's social institutions and the power structures to which they give rise, or vice versa. He works out, in concrete terms, the conflicts and issues of his times, both in his own state of Bengal and in the larger Indian nation' (Cooper, 2000, p. 2). But it can hardly be denied that, like its adapted text Premchand's 'Sadgati', Ray's film adaptation 'Sadgati' raises serious questions on Ray's perspective in handling the caste question, and has become, as evident from the critical writings on the representation of Dalits in the film, a potential repository of conflict apropos the 'more appropriate' version of Dalit 
consciousness, which can be instrumental to the constructive development of larger Dalit politics and the cause of Dalit empowerment.

\section{Acknowledgement}

An earlier draft version of the article entitled “The 'Sadgati' ('deliverance') of the Caste Question: Sadgati as the Repository of Conflict between the 'Casteless' Consciousness and the Anti-Caste Dalit Consciousness" was presented as a paper in the International Seminar on "Exploring the History of Adivasis, Dalits and Minorities in India", organized by the Department of History, University of Gour Banga, Malda (26 April, 2019).

\section{References}

Biswas, Moinak. (1999). Bengali Film Debates: The Literary Liason Revisited. Journal of the Moving Image, Autumn (1), 1-18. https://jmionline.org/article/bengali film debates the literary liaison revisited

Brueck, L. (2010). The Emerging Complexity of Dalit Consciousness. Himal South Asian, 23(1), 44-47.

Cooper, Darius. (2000). 'Introduction' to The Cinema of Satyajit Ray between Tradition and Modernity. Cambridge: Cambridge University Press.

Essays, UK. (November 2018). Neo Realism Of Pather Panchali Film Studies Essay. Retrieved from https://www.ukessays.com/essays/film-studies/neo-realism-of-pather-panchali-film-studiesessay.php?vref=1

Haider, Nishat. (2016). In Quest of a Comparative Poetics: A Study of Sadgati. In M. Asaduddin (Ed.), Premchand in World Languages: Translation, reception and cinematic representations (pp. 195-211). New York: Routledge.

Hunt, Sarah Beth. (2014). Hindi Literature and the Politics of Representation. Delhi: Routledge.

Josan, Renu. (2012). Oppression to Assertion: Dalit Consciousness in Omprakash Valmiki's Joothan, Journal of Teaching and Education, 1(4), 7-12. http://www.universitypublications.net/jte/o104/pdf/FIR212.pdf

Kant, Yashika. (2017). Approaching the Question of Caste Subjugation in Premchand's Stories Kafan and Sadgati and Analyzing them with Reference to Dominant Trends Noticed in Dalit Literature. Veda's Journal of English Language and Literature-JOELL, 4(4), 187-193. Retrieved from http://joell.in/wpcontent/uploads/2017/12/CASTE- SUBJUGATION- IN-PREMCHAND\%E2\%80\%99S-STORIES.pdf

Kumar, Raj. (2010). Dalit Literature: A Perspective from Below. In Imtiaz Ahmad and Shashi

Bhushan Upadhyay (Eds.), Dalit Assertion in Society, Literature and History (pp. 129-141). New Delhi: Orient BlackSwan in association with Deshkal Society.

Limbale, Sharankumar. (2004, 2016). Towards an Aesthetic of Dalit Literature: History, Controversies and Considerations, trans. Alok Mukherjee. New Delhi: Orient BlackSwan.

Muktibodh, Sharatchandra. (1992). What is Dalit Literature?. In Arjun Dangle (ed.), Poisoned Bread: Translations from Modern Marathi Dalit Literature (pp. 267-70). Delhi: Orient Longman.

Premchand, Munshi. (2018). “Salvation”, Stories on Caste, ed. M. Asaduddin. Gurgaon: Penguin Random House, 06-16.

Ray, Satyajit. (1976). Our Films, Their Films. Hyderabad: Orient Blackswan. 
Sadgati. Directed by Satyajit Ray,1981.

Upadhyay, Shashi Bhushan. (2010). Premchand and Dalit Literature: Representation of Dalits in the Literature of Premchand. In Imtiaz Ahmad and Shashi Bhushan Upadhyay (Eds.),

Dalit Assertion in Society, Literature and History (pp. 156-195). New Delhi: Orient BlackSwan in association with Deshkal Society.

Valmiki, Omprakash. (2014, 2019). Dalit Sahitya ka Saundarya Sastra (Aesthetics of Dalit Literature). Delhi: Radhakrishna Prakashan Pvt. Ltd.

Zutshi, Deepti. (2012). Satyajit Ray's Deliverance of Premchand's 'Sadgati'. In M. Asaduddin and Anuradha Ghosh (Eds.), Filming Fiction: Tagore, Premchand, and Ray (pp. 239-260). New Delhi: OUP. 